\title{
MENINGKATKAN KREATIVITAS MENULIS MAHASISWA MELALUI METODE MENULIS PENGALAMAN PRIBADI
}

\author{
Arfin, Pahenra, Asrul \\ Universitas Muhammadiyah Kendari \\ arfinfine7@gmail.com
}

\begin{abstract}
ABSTRAK
Tujuan dalam penelitian ini adalah untuk membuktikan apakah kreativitas menulis mahasiswa dapat ditingkatkan melalui metode menulis pengalaman pribadi. Jenis penelitian ini adalah penelitian tindakan kelas, dengan faktor yang diteliti yaitu faktor kreativitas mahasiswa dan faktor metode. Penelitian dilaksanakan melalui prosedur perencanaan tindakan, pelaksanaan tindakan, observasi dan penilaian, serta refksi. Data dikumpulkan dengan cara teknik tes dan non tes, kemudian dianalisis secara analisis kuantitatif dengan indikator berhasilan $76 \%$ secara individu maupun secara klasikal. Metode menulis pengalaman pribadi dilaksanakan dengan prosedur yaitu menetapkan mata kauliah dan membuat perencanaan perkuliahan, menyusun sistematika penulisan pengalaman pribadi dalam bentuk lembar kerja mahasiswa, penyajian materi perkuliahan, pemberian contoh pengalaman pribadi sesuai dengan materi perkuliahan, Dosen memberikan tugas kepada mahasiswa untuk menulis pengalaman pribadi, Dosen menjelaskan langkah-langkah menulis pengalaman pribadi sesuai dengan lembar kerja mahasiswa, dan Dosen melakukan penilaian. Hasil penelitian yaitu kreativitas menulis mahasiswa dapat ditingkatkan dengan menggunakan metode menulis pengalaman pribadi di Program Studi Administrasi Pendidikan Universitas Muhammadiyah Kendari, dengan nilai rata-rata secara klasikal $76,15 \%$ yang sebelumnya nilai rata-rata kreativitas menulis mahasiswa berkisar $58,45 \%$ pada pratindakan dan $63,18 \%$ pada tindakan siklus I. Kemampuan dan keterampilan menulis mahasiswa dikategorikan kreatif dan memenuhi nilai ketuntasan minimal $76 \%$.
\end{abstract}

Katakunci: kreativitas menulis, metode menulis, pengalaman pribadi

\section{ABSTRACT}

The purpose of this research is to prove whether students' writing creativity can be improved through the method of writing personal experiences. This type of research is classroom action research, with the factors examined are student creativity and method factors. The research was carried out through the procedures of action planning, action implementation, observation and assessment, and reflection. Data were collected by means of test and non-test techniques, then analyzed in quantitative analysis with $76 \%$ success indicators individually and classically. The method of writing personal experiences is carried out by the procedure of setting course subjects and planning lectures, compiling a systematic writing of personal experiences in the form of student worksheets, presenting lecture material, giving examples of personal experiences in accordance with lecture material, lecturers assigning assignments to students to write personal experiences, The lecturer explains the steps of writing personal experiences according to the student worksheet, and the lecturer makes an assessment. The results of the study are the creativity of writing students can be improved by using the method of writing personal experience in the Educational Administration Study Program at the University of Muhammadiyah Kendari, with an average classical score of $76.15 \%$, previously the average value of student writing creativity ranged from $58.45 \%$ to pre-action and $63.18 \%$ in the cycle action 1 . The ability and writing skills of students are categorized as creative and meet the minimum completeness value of $76 \%$.

Keywords: writing creativity, writing methods, and personal experience 


\section{PENDAHULUAN}

Perkembangan teknologi dan informasi komunikasi sekarang ini begitu sentral diberbagi aspek kehidupan, terutama dalam dunia pendidikan. Dengan adanya teknologi informasi dan komunikasi dapat menjadi media dan sumber belajar yang dapat dimanfaatkan oleh dosen dan mahasiswa dalam proses pembelajaran. Segala sesuatu informasi terkait dengan materi pembelajaran dapat diakses kapan saja dan dimana saja melalui internet tampa ada batasan waktu. Terkait dengan hal tersebut, ternyata disisi lain memiliki dampak yang negatif bagi mahasiswa dari pengunaan teknologi informasi dan komunikasi khusunya adalah internet. Salah satu penyalahgunaan internet bagi mahasiswa adalah budaya copy paste dalam menyelesaikan tugas-tugas perkuliahan, yang mengakibatkan mahasiswa tidak memiliki kreativitas menulis. Ketika ada tugas mata kuliah, mahasiswa tidak perlu menguras pikiran dalam menyusun tugas tetapi cukup browsing di internet, tugastugas kuliah dalam hitungan menit dapat diselesaikan.

Fenomena uraian tersebut, terjadi pada mahasiswa di Program Studi Administrasi pendidikan Universitas Muhammadiyah Kendari, dimana kreativitas menulis mahasiswa sangat kurang dan cenderung terbiasa dengan budaya copy paste. Hal ini terlihat ketika mahasiswa diberikan tugas individu dalam membuat makalah pada mata kuliah pengantar administrasi pendidikan, rata-rata terjadi kecenderungan tugas yang dibuatnya sama karena tugas yang dibuatnya hasil downdload dari internet, tanpa tau temannya mendowndload tugas yang sama pula. Dengan demikian untuk mengatasi hal tersebut perlu ada metode yang digunakan untuk meningkatkan kreativitas menulis mahasiswa yaitu metode menulis pengalaman pribadi yang materinya dapat disesuaikan dengan mata kuliah yang diprogram oleh mahasiswa.

Mahasiswa sebagai generasi pelanjut tatanan kehidupan bangsa, jika tidak memiliki kreativitas terutama dalam hal menulis, maka tidak akan memiliki gagasan untuk menbangun bangsanya, karena dia terbiasa menjiblak dan bahkan akan menjadi masyarakat konsumtif. Tarigan (Ngudiana, 2016) mengungkapkan bahwa kreativitas menulis tidak terbentuk dengan sendirinya tetapi dibutuhkan latihan yang cukup dan teratur serta pendidikan yang terprogram. Oleh karena itu, pengembangan kreativitas menulis mahasiawa dapat dilakukan dengan berbagai cara, salah satunya adalah melalui kegiatan menulis pengalaman pribadi. Sebagaimana hasil penelitian yang telah dilakukan sebelumnya, yaitu hasil penelitian oleh Prabawati (2013) bahwa keterampilan menulis siswa dapat ditingkatkan melalui menulis pengalaman pribadi, dimana nilai 
rata-rata siswa pada tahap observasi mencapai 60 kemudian setelah dilakukan tindakan dengan awal pertemuan meningkat menjadi 61,31 dan akhir pertemuan meningkat menjadi 80,25 atau meningkat sebanyak 18,94 atau sebesar $30,89 \%$ dari observasi dan awal pertemuan. Oleh sebab itu, upaya dalam mengatasi rendahnya kreativitas menulis mahasiswa dan yang berperan dalam mengembangkan metode yang digunakan adalah dosen. Selayaknya dosen dapat menjadi mentor yang selalu memperhatikan tingkat perkembangan kreativitas menulis mahasiswa baik secara individu maupun secara klasikal. Pengembangan kreativitas menulis mahasiswa dapat dilakukan oleh dosen selama proses pembelajaran, baik di dalam kelas ataupun di luar kelas.

Gagne (Andheska, 2016) kreativitas akan muncul pada diri individu bila ada tantangan baru yang solusinya tidak rutin. Kreativitas dapat dibentuk dan dilatih dalam proses pembelajaran yang berprinsip pada konstruktivisme, melalui penyelidikan, konjektur, penemuan, dan generalisasi. Dapat dijelaskan bahwa kreativitas akan muncul berkenaan dengan kesadaran adanya kesenjangan antara pengetahuan siap dengan pengetahuan baru, kemudian muncullah beragam alternatif solusi.

Andheska (2016) secara etimologis, kreativitas (creativity) berasal dari kata "mencipta" (to creat) yang berarti mempunyai sifat kreatif (creative). Berdasarkan hal tersebut, kreativitas dapat didefinisikan sebagai kemampuan seseorang dalam menciptakan sesuatu (ide-caraproduk) yang baru. Konotasi kreativitas ini berkaitan dengan sesuatu yang baru yang sifatnya masih orisinal. Ausubel (Hamalik, 2002) mengatakan bahwa kreativitas adalah kemampuan atau kapasitas pemahaman, sensitivitas, dan apresiasi dalam menyelesaikan suatu permasalahan. Aspek lain dari kreativitas adalah kemampuan berpikir divergen, yaitu meliputi orisinalitas, fleksibilitas, kualitas, dan kuantitas.

Permatasari (2014) kreativitas adalah kemampuan berpikir tentang sesuatu dengan cara baru dan menghasilkan solusi yang unik atas suatu problem. Kaufman (Wonopuspito dan Cahyono, 2014) mengungkapkan bahwa kreativitas dapat diartikan sebagai kemampuan dalam menciptakan sesuatu yang baru yang mencakup divergent thinking, yaitu proses menyusun gagasan-gagasan baru yang berbeda, yang menurut Guilford memiliki empat aspek utama atau aspek kunci (key aspect) yaitu: pertama adalah kelancaran (fluency) yang menekankan pada jumlah atau banyaknya hasil, terlepas dari adanya pengulangan (repetitiveness) atau tidak. Karena itu, kelancaran individu dapat dilihat dari banyaknya respon 
yang dimunculkan. Dalam menulis, individu akan memunculkan sejumlah kata untuk dirangkai dalam tulisan yang dibuatnya. Kelancaran dapat dilihat dari jumlah kata yang dihasilkan.

Kedua adalah aspek Kelenturan (flexibility) yang menekankan pada jumlah kategori atau jenis respon berbeda pada stimulus. Karena itu, kelenturan individu dapat dilihat dari berapa banyak kategori berbeda yang dapat dimunculkan, sehingga pengulangan tidak akan diperhitungkan. Kelenturan individu dalam menulis dapat dilihat dari jumlah kosakata berbeda yang dimilikinya. Karena itu, aspek kelenturan dalam menulis akan dilihat dari jumlah kata yang dihasilkan sama seperti aspek kelancaran. Perbedaannya, pengulangan kata tidak akan diperhitungkan karena yang dicari adalah banyaknya kosakata yang dipakai oleh individu.

Ketiga adalah aspek originalitas atau keunikan (originality) yang menekankan pada kemampuan untuk mencetuskan suatu gagasan yang asli, unik, langka atau tidak lazim. Salah satu cara mudah dalam melihat originalitas adalah dengan menghadapkan sekelompok orang dengan persoalan yang sama kemudian melihat jawaban mereka dan dibandingkan satu dengan yang lain. Karena itu aspek originalitas dalam tulisan dapat dilihat dengan cara membandingkan hasil tulisan individu dengan individu lainnya, kemudian diamati hal apa yang unik dalam tulisan individu tersebut.

Keempat adalah aspek elaborasi mengacu pada pengembangan ide ke dalam bentuk yang lebih mendetail. Elaborasi lebih menekankan pada kemampuan untuk menjelaskan sesuatu secara terperinci. Ketika menulis, individu akan memaparkan gagasan yang ingin disampaikannya dalam tulisan tersebut. Dalam menulis, individu dituntut untuk mendeskripsikan gagasan dan pemikirannya tersebut secara nyata dalam bentuk rangkaian kalimat. Karena itu, untuk melihat aspek elaborasi individu, perlu diamati bagaimana cara individu menjelaskan atau mendeskripsikan segala sesuatu di dalam tulisannya dalam bentuk yang mendetail.

Ciri-ciri kreativitas menurut Munandar (Permatasari, 2014) dikategorikan menjadi dua ciri yaitu ciri kognitif (berpikir kreatif) dan ciri afektif (sikap kreatif). Ciri Kognitif (berfikir kreatif) mencakup: 1) keterampilan berfikir lancar (Fluency) yakni keterampilan mencetuskan banyak gagasan, jawaban, penyelesaian masalah, atau pertanyaan dengan memberikan banyak cara atau saran. 2) keterampilan berpikir luwes (flexibility) yakni keterampilan mengahasilkan suatu gagasan, jawaban, atau pertanyaan yang bervariasi dengan melihat masalah dari sudut padang yang berbedabeda, serta mampu mencari banyak 
alternatif sehingga mampu mengubah cara pendekatan atau cara pemikiran. 3) keterampilan berfikir orisinal (originalitas) yakni keterampilan yang melahirkan ungkapan baru dan unik dengan memikirkan cara yang tidak lazim untuk mengungkapkan diri serta membuat kombinasi yang tidak lazim dari bagian-bagian atau unsur-unsur. 4) keterampilan memperinci (elaborasi) yakni keterampilan memperkaya dan mengembangkan suatu gagasan atau produk dan menambahkan atau memperinci secara detail dari suatu obyek, gagasan atau situasi sehingga menjadi lebih menarik.

Ciri Afektif (sikap kreatif) mencakup: 1) rasa Ingin tahu yaitu selalu terdorong untuk mengajukan banyak pertanyaan, selalu memperhatikan obyek, dan situasi peka dalam pengamatan. 2) bersifat Imajinatif yaitu mampu memperagakan atau membayangkan hal-hal yang tidak atau belum pernah terjadi. 3) merasa tertantang oleh kemajemukan yaitu terdorong untuk mengatasi masalah yang sulit dan merasa tertantang oleh situasi-situasi yang sulit serta lebih tertarik pada tugas-tugas yang sulit. 4) sifat berani mengambil resiko yaitu berani memberikan jawaban meskipun belum tentu benar, tidak takut gagal atau mendapat kritik. 5) Sifat menghargai yaitu dapat menghargai bimbingan dan pengarahan dalam hidup serta menghargai kemampuan dan bakat-bakat sendiri yang sedang berkembang.

Upaya meningkatkan kreativitas menulis mahasiswa adalah bertujuan untuk membuktikan apakah kreativitas menulis mahasiswa di program studi Administrasi Pendidikan Universitas Muhammadiyah Kendari dapat ditingkatkan melalui metode menulis pengalaman pribadi. Pengalaman pribadi adalah peristiwa yang dialami seseorang yang memiliki karakteristik tempat dan waktu kejadian yang telah berlalu. Husnun (Ngudiana, 2016) mengungkapkan langkah-langkah menulis pengalaman pribadi adalah memilah dan menentukan pengalaman yang menarik, menyusun urutan peristiwa dalam bentuk kerangka, membuat judul pengalaman yang dirasakan atau dilaksanakan ketika berkunjung pada tempat-tempat tertentu yang dianggap penting, dan mengembangkan kerangka pengalaman.

\section{METODE}

Metode penelitian yang digunakan adalah penelitian tindakan kelas, yang kegiatan penelitiannya dimulai dengan kegiatan pratindakan (obervasi awal) dan selanjutkan ditindaklanjuti dengan kegiatan tindakan penelitian sesuai siklus yang telah direncankan. Tahapannya disesuikan dengan proses perkuliahan pada mata kuliah pengantar administrasi pendidikan di Program 
Studi Administrasi Pendidikan berjumlah 37 orang dan 2 orang Universitas Muhammadiyah Kendari dosen pengampuh mata kuliah pada Bulan April-September 2019 Pengantar Administrasi Pendidikan. Tahun Ajaran 2018/2019 semester 2 (dua). Tindakan penelitian yang dilaksanakan adalah sebagai upaya meningkatkan kreativitas menulis mahasiswa melalui metode menulis pengalaman pribadi. Subjek penelitian ini adalah mahasiswa yang Faktor yang diteliti adalah faktor kreativitas mahasiswa dan faktor metode yang digunakan. Prosedur pelaksanaan tindakan penelitian ini dapat digambarkan dalam siklus sebagai berikut.

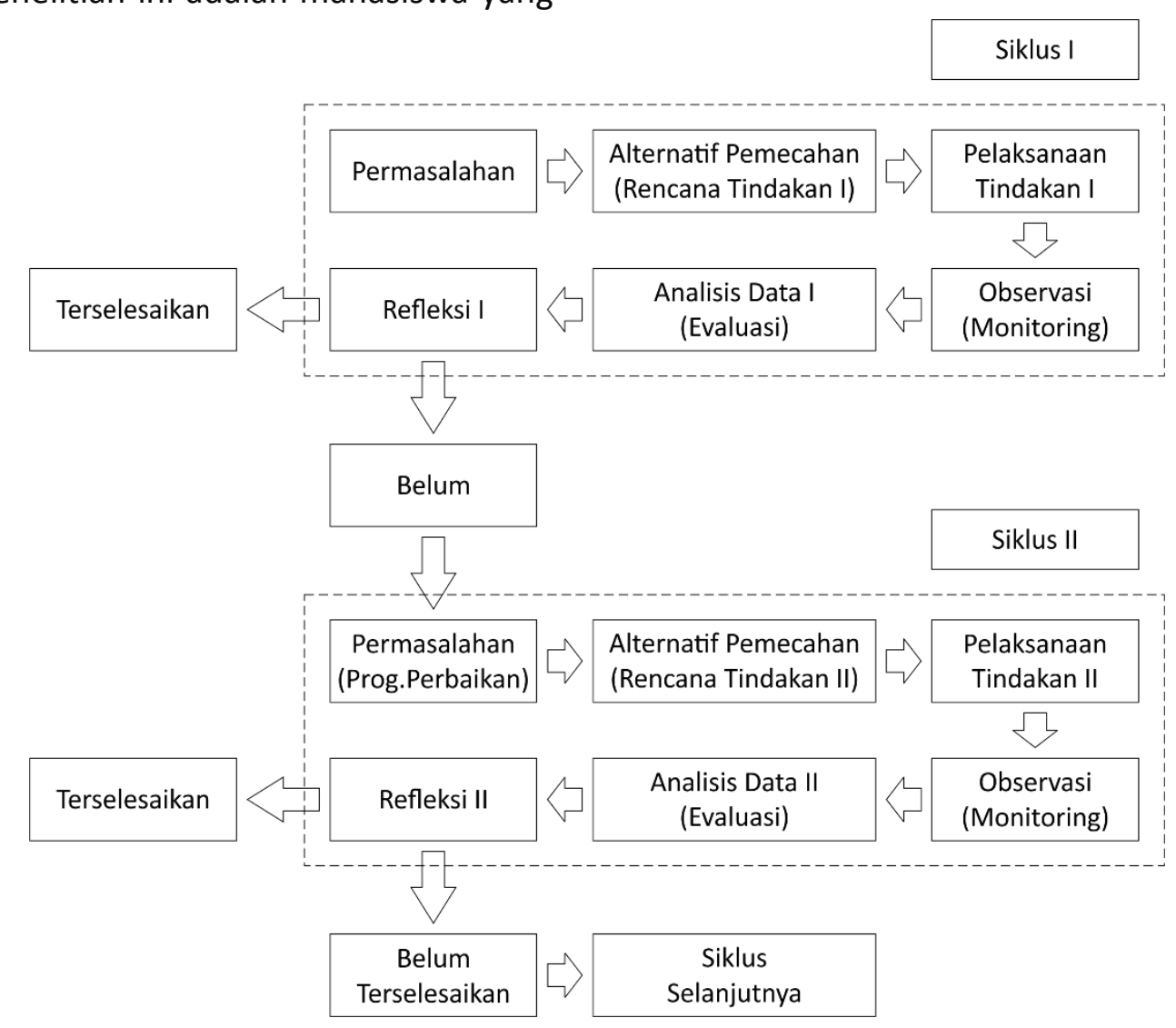

Gambar 1. Siklus Penelitian Tindakan Kelas Kurt Lewin (Arikunto, 2006)

Teknik pengumpulan data yang digunakan adalah teknik tes dan teknik non tes. Teknik tes digunakan untuk mengukur seberapa besar tingkat kreativitas mahasiswa dalam menulis pengalaman pribadi. Indikator penilaian untuk mengukur kreativitas mahasiswa dalam menulis pengalaman pribadi menguanakan kriteria skala likert (Sugiyono, 2014) dengan ketentuan: (1) sangat kreatif (SK) diberikan skor 5; (2) Kreatif (K) diberikan skor 4; (3) Sedang-sedang (SS) diberikan skor 3; (4) tidak kreatif (TK) diberikan skor 2; dan (5) sangat tidak kreatif (STK) diberikan skor 1. Teknik non tes yang digunakan adalah observasi. Aspek-aspek yang diamati 
meliputi: (1) persiapan dosen dan kesiapan mahasiawa mengikuti perkuliahan, (2) penjelasan dosen dan mahasiswa mendengarkan atau memperhatikan penjelasan dosen, (3) ketertarikan pada materi perkuliahan, (4) ketertarikan dengan media yang digunakan, (5) mengajukan pertanyaan pada dosen jika mengalami kesulitan dalam proses pembelajaran, (6) memperlihatkan media yang digunakan dalam pembelajaran, (7) keseriusan mahasiswa dalam menulis pengalaman pribadi, (8) mahasiswa mampu mengerjakan tugas menulis pengalaman pribadi sesuai dengan waktu yang ditetapkan.

Teknik analisis data yang digunakan adalah teknik analis data kuantitatif, dimana setelah data terkumpul maka langkah selanjutnya adalah menghitung persentase kreativitas menulis mahasiswa melalui metode menulis pengalaman pribadi dengan mengunakan rumus sebagai berikut.

Nilai $=\frac{\text { skor yang dicapai mahasiswa }}{\text { skor tertinggi yg mungkin dicapai }} \times 100$

\section{Indikator keberhasilan yang ditetapkan dalam mengukur kreativitas menulis mahasiswa} melalui metode menulis pengalaman pribadi yaitu jika nilai secara individu maupun secara klasikal dari hasil penilaian mencapai $76 \%$. Skor persentase dikonversi ke dalam kategori penilaian yang ditetapkan di Program Studi Administasi Pendidikan Universitas Muhammadiyah Kendari ditunjukkan pada tabel 1 berikut.

Tabel 1. Kategori penilaian

\begin{tabular}{|c|c|}
\hline Interval Nilai & Tingkat Penugasan \\
\hline $86-100$ & Sangat kreatif \\
\hline $76-85$ & Kreatif \\
\hline $60-75$ & Sedang-sedang \\
\hline $50-59$ & Tidak kreatif \\
\hline$<49$ & Sangat tidak kreatif \\
\hline
\end{tabular}

\section{HASIL DAN PEMBAHASAN}

\section{Hasil Penelitian}

Kriteria penilaian yang digunakan untuk mengukur kreativitas menulis mahasiswa melalui metode menulis pengalaman pribadi di Program Studi administrasi Pendidikan Universitas Muhammadiyah Kendari adalah menggunakan 8 (delapan) kriteria yaitu: kelancaran (fluency), kelenturan (flexibility), isi tulisan bersifat orisinal, elaborasi, kejelasan referensi yang digunakan, penggunaan bahasa yang baik, keterkaitan isi tulisan dengan dengan topik yang diberikan, dan sesuai dengan sistematika penulisan. Penilaian kreativitas menulis mahasiswa pada kegiatan pratindakan ditunjukkan pada gambar 2. 


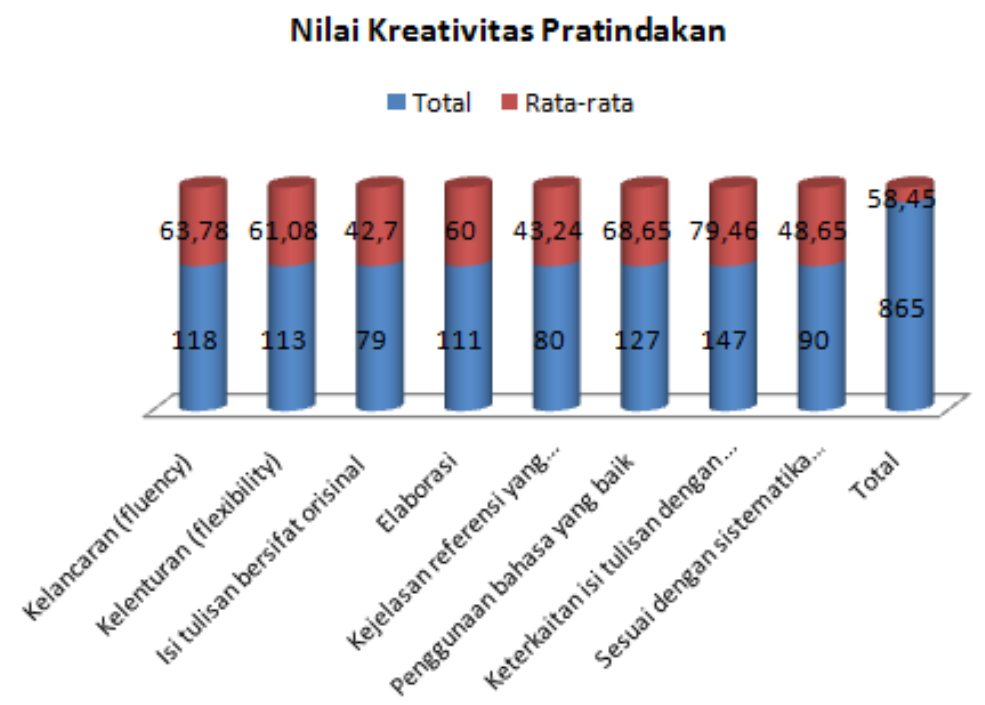

Gambar 2. Histogram Nilai Pratindakan

Nilai kreativitas menulis mahasiswa di atas menunjukkan bahwa rata-rata kreativitas menulis 37 orang mahasiswa dari keseluruhan indikator adalah 58,45 dengan total 865 skor dari skor ideal yaitu 1480 . Dengan demikan, skor 58,45 menunjukkan bahwa kreativitas menulis mahasiswa dikategorikan tidak kreatif.

Upaya meningkatkan kreativitas menulis mahasiswa, maka digunakan metode menulis pengalaman pribadi dengan pokok pembahasan fungsifungsi administrasi pendidikan. Adapun tahapan tindakan siklus I yang dilakukan yaitu: pertama adalah kegiatan perencanaan dalam merapkan metode menulis pengalaman pribadi dengan menyediakan perangkat perkuliahan berupa recancana pelaksanaan perkuliahan, bahan ajar, media presentasi powerpoint, lembar kerja mahasiswa, lembar observasi, dan lembar penilaian.
Kedua adalah pelaksanaan tindakan yaitu penyajian materi dan diskusi. Materi yang telah dikuasai oleh mahasiswa dalam kegiatan penyajian materi maupun kegiatan diskusi ditindaklanjuti dengan menganalisis pengalaman pribadi mahasiswa yang memiliki keterkaitan dengan fungsi-fungsi administrasi pendidikan. Dalam kegiatan ini digunakan metode menulis pengalaman pribadi, dengan tujuan meningkatkan kreativitas menulis mahasiswa, maupun sebagai upaya untuk mempertajam kemampuan analisis mahasiswa terkait dengan fungsi-fungsi administrasi pendidikan yang telah implementasikan dilapangan. Dalam kegiatan ini, dosen menyediakan Lembar Kerja Mahasiswa (LKM), sebagai panduan dan petunjuk bagi mahasiswa dalam menulis pengalaman pribadinya. Untuk mengetahui operasional penggunaan LKM, dosen menjelaskan cara untuk menyelesaikan LKM dari 
setiap komponennya dan pribadinya sesuai dengan aktifitas memberikan contoh. Setelah perkualiahan yang telah disusun oleh mahasiswa, menyatakan pemahamannya terkait dengan operasional penggunaan LKM, maka mahasiswa melanjutkan dengan aktifitas menulis pengalaman dosen. Ketiga adalah kegiatan evaluasi yaitu melakukan penilaian kreativitas mahasiswa dalam menulis pengalaman pribadi. Hasil penilaian tersebut ditunjukkan pada gambar 3 .

\section{Nilai Kreativitas Tindakan Siklus 1}

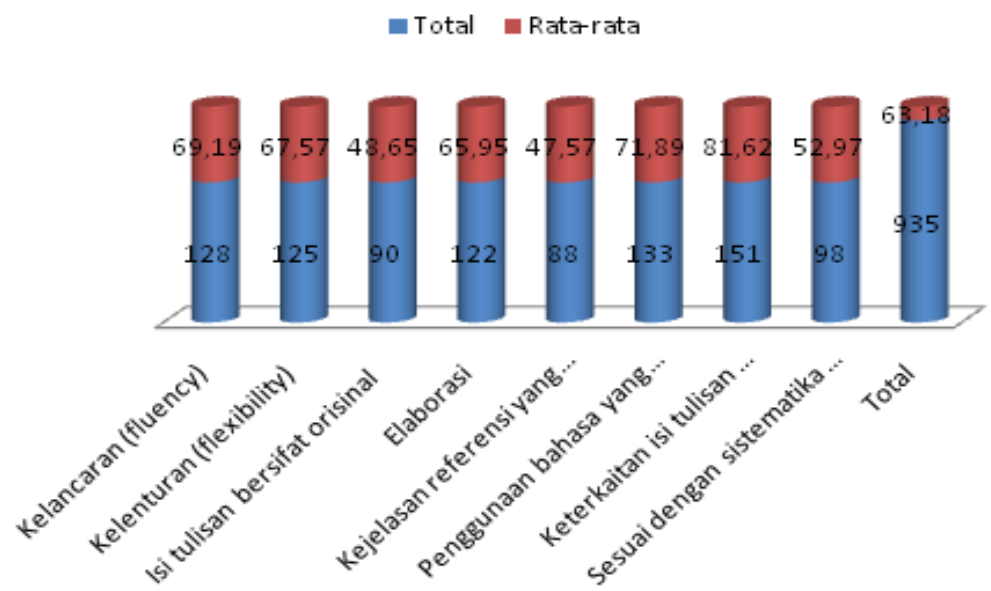

Gambar 3. Histogram Nilai Siklus I

Nilai kreativitas menulis mahasiswa di atas menunjukkan bahwa rata-rata kreativitas menulis 37 orang mahasiswa dari keseluruhan indikator adalah 63,18 dengan total 935 skor dari skor ideal yaitu 1480 . Dengan demikan, skor 63,18 menunjukkan bahwa kreativitas menulis mahasiswa dikategorikan sedang-sedang.

Keempat adalah kegiatan refleksi. Pada kegiatan ini ditemukan bahawa hasil evaluasi tentang kreativitas mahasiswa melalui metode menulis pengalaman pribadi menunjukkan peningkatan. Namun belum mencapai idikator keberhasilan secara klasikal dengan nilai batas minimal yaitu $76 \%$. Bebera penyebabnya adalah Pemberian contoh pengalaman pribadi yang dikaitkan dengan materi, dosen mencontohkan dalam bentuk cerita secara lisan, bukan secara tertulis. Sehingga mahasiswa merasa kesulitan mengikuti alur LKM yang disediakan, tanpa ada contoh tulisan pengalaman pribadi sesuai dengan format LKM. Mahasiwa masih kesulitan memadukan antara refensi yang digunakan dengan isi pengalaman, kutipan dari referensi hanya sebatas pelengkap tulisan, sehingga orisinal tulisan dan kejelasan referensi masih kurang. 
Kreativitas menulis direncanakan kembali dalam rangka membutuhkan pembiasaan yang untuk mencapai hasil yang maksimal. berulang-ulang, yang perlu Dengan demikian, pelaksanaan diintegrasikan setiap pertmuan tindakan dilanjutkan pada siklus II, perkulihan. Sehingga hasil penilainnya adalah sebagai pengorganisasian perkulihan perlu berikut.

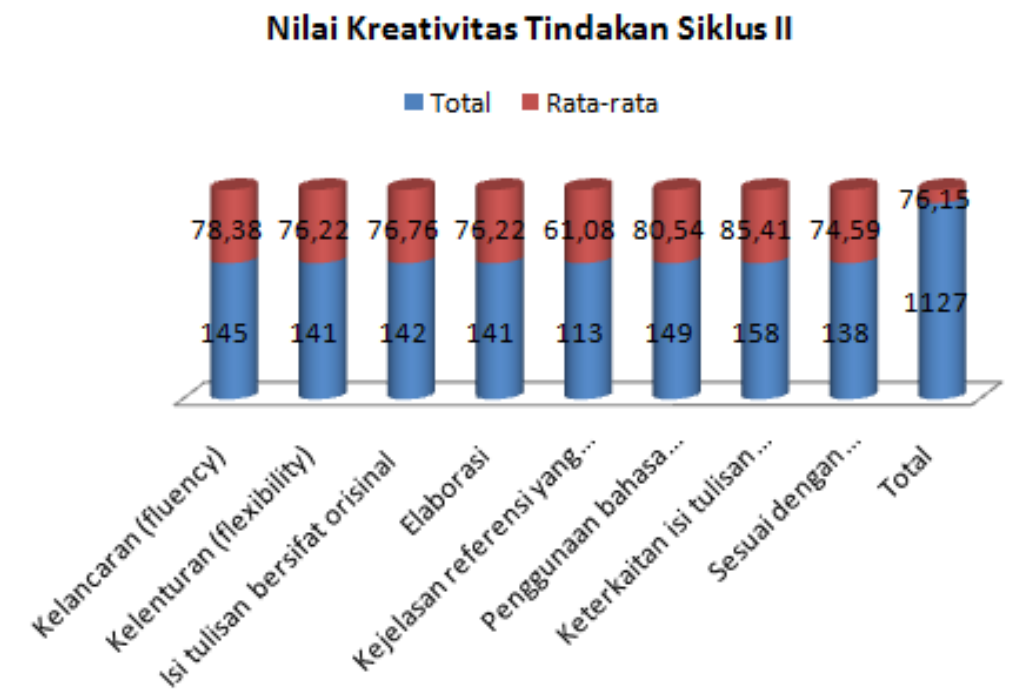

Gambar 4. Histogram Nilai Siklus II

Nilai kreativitas menulis individu maupun secara klasikal. mahasiswa di atas menunjukkan Dimana kreativitas menulis bahwa rata-rata kreativitas menulis mahasiswa secara klasikal pada 37 orang mahasiswa dari keseluruhan pratindakan adalah 58,45\% indikator adalah 76,15 dengan total meningkat $63,18 \%$ pada siklis I dan 1127 skor dari skor ideal yaitu 1480 . meningkat $76,15 \%$ pada sisklus II. Dengan demikan, skor 76,15 Adapun kontribusi metode penulisan menunjukkan bahwa kreativitas pengalaman pribadi dalam menulis mahasiswa dikategorikan menigkatkan kreativitas menulis kreatif dan telah memenuhi mahasiswa yaitu setiap pengalaman ketuntasan minimal. bersifat orisinal dan dapat menjadi

\section{Pembahasan}

Metode menulis pengalaman pribadi dapat meningkatkan kreativitas menulis mahasiswa di Program Studi Administrasi Pendidikan dengan kriteria ketuntasam minimal $76 \%$ secara menarik jika diintegrasikan dengan materi perkuliahan yang telah dipelajari oleh mahasiswa. Efektifitas penggunaan metode menulis pengalaman pribadi dalam meningkatkan kreativitas menulis mahasiswa pada mata kulaiah pengatar administrasi pendidikan 
dengan materi fungsi-fungsi administrasi pendidikan yaitu sebagai berikut.

1. Identifikasi materi yang akan diintegrasikan dengan pengalaman pribadi mahasiswa,

2. Pengambilan keputusan yaitu penyusunan rencana pembelajaran, pemilihan media, penentuan indikator penilaian, penyediaan perangkat pembelajaran.

3. Penyajian materi yang akan diitegrasikan dengan kegiatan menulis pengalaman pribadi dengan mengunakan strategi yang tepat.

4. Pelaksanaan kegiatan menulis pengalaman pribadi dengan menyediaan waktu yang cukup dan penyediaan kondisi yang memungkinkan mahasiswa dapat menulis pengalamannya dengan baik. Kegiatan menulis pengalaman pribadi dapat dilaksanakan di dalam kelas maupun dalam bentuk penugasan yang dikerjakan di rumah.

5. Penilaian tulisan pengalaman pribadi mahasiswa sesuai dengan indikator penilaian yang telah ditetapkan.

6. Umpan balik berdasarkan hasil penilaian.

\footnotetext{
Beberapa uraian di atas menunjukkan bahwa kreativitas menulis merupakan suatu bentuk keterampilan yang dapat diwujudkan dengan pembiasaan menulis. Metode
}

menulis pengalaman pribadi merupakan salah satu bentuk upaya penciptaan kondisi dalam pembiasaan mahasiswa dalam menulis secara orisinal dan menghindarkan mahasiswa dari budaya copy paste atau plagiat. Sebagaimana yang diungkapkan oleh Ausubel (Hamalik, 2002) mengatakan bahwa kreativitas adalah kemampuan atau kapasitas pemahaman, sensitivitas, dan apresiasi dalam menyelesaikan suatu permasalahan. Aspek lain dari kreatifitas adalah kemampuan berpikir divergen, yaitu meliputi orisinalitas, fleksibilitas, kualitas, dan kuantitas.

\section{KESIMPULAN}

Kreativitas menulis mahasiswa dapat ditingkatkan dengan menggunakan metode menulis pengalaman pribadi di Program Studi Administrasi Pendidikan Universitas Muhammadiyah Kendari, dengan nilai rata-rata secara klasikal $76,15 \%$ yang sebelumnya nilai rata-rata kreativitas menulis mahasiswa berkisar $58,45 \%$ pada pratindakan dan 63,18\% pada tindakan siklus I. Kemampuan dan keterampilan menulis mahasiswa dikategorikan kreatif dan memenuhi nilai ketuntasan minimal $76 \%$. 


\section{DAFTAR PUSTAKA}

Andheska, Harry. 2016. Membangun Kreativitas Siswa Dalam Pembelajaran Menulis Dengan Memanfaatkan Media Pembelajaran Inovatif. Yogyakarta: Jurnal Bahastra, Oktober 2016, Volume XXXVI, Nomor 1.

Arikunto, Suharsimi. 2006. Penelitian Tindakan Kelas. Jakarta: Bumi Aksara.

Hamalik, Oemar. 2002. Perencanaan Pengajaran Berdasarkan Pendekatan Sistem. Jakarta: Bumi Aksara.

Ngudiana. 2016. Peningkatan Keterampilan Menulis Pengalaman Pribadi Melalui Strategi Modelling. Jurnal Wahana Pedagogika, Vol. 2, No. 1.

Permatasari, RW. 2014. Penerapan Metode Bercerita Untuk Meningkatkan Kreativitas pada Siswa TK Kelompok B. Surabaya: Jurnal PG-PAUD Trunojoyo, Volume 1, Nomor 1, April 2014, hal 1-75.

Prabawati, Anisa. 2013. Peningkatan Keterampilan Menulis Cerpen Berdasarkan Pengalaman Pribadi Dengan Metode Kuantum pada Siswa Kelas IX SMP N 11 Purworejo Tahun Pelajaran 2012/2013. Jurnal Pendidikan Bahasa dan Sastra Indonesia. Vol 1, No. 1. http://garuda.ristekdikti.go.id

Sugiyono. 2014. Metode Penelitian Manajemen. Bandung: Al Fabeta.
Wonopuspito, TS \& Cahyono R. 2014. Perkembangan Kreativitas dalam Menulis Berbahasa Inggris Pada Roleplayer. Surabaya: Jurnal Psikologi Pendidikan dan Perkembangan Vol. 3 No. 02. 